\title{
Leg tissue composition and physico-chemical parameters of sheep meat fed annatto coproduct
}

\section{Composição tecidual da perna e parâmetros físico-químicos da carne de ovinos alimentados com subproduto do urucum}

\author{
Dorgival Morais de Lima Júnior ${ }^{1 *}$; Francisco Fernando Ramos de Carvalho²; \\ Maria Inês Sucupira Maciel²; Stela Antas Urbano ${ }^{3}$; Juliana Paula Felipe de \\ Oliveira $^{4}$; Adriano Henrique do Nascimento Rangel ${ }^{3}$
}

\begin{abstract}
Our objective was to evaluate leg tissue composition and physico-chemical quality parameters of sheep meat fed with increasing levels of annatto coproduct. 32 male uncastrated animals without a defined breed were randomized in four treatments $\left(0,100,200\right.$ and $300 \mathrm{~g} \mathrm{~kg}^{-1}$ of annatto coproduct in the DM diet). After 78 days of confinement, the animals were slaughtered and body components were recorded. Reconstituted leg weight, total muscle weight, biceps weight and semitendinosus weight showed a negative linear behavior $(\mathrm{P}<0.05)$ with the inclusion of the annatto coproduct in the diet. No effects of the inclusion of annatto coproduct $(\mathrm{P}>0.05)$ were found for leg tissue composition (\%), muscle:bone ratio, relative fat or leg muscle. Meat physico-chemical parameters (color, shear force, water retention capacity and cooking losses) were not affected by the inclusion of the annatto coproduct in the diet. The annatto coproduct can be included in up to $300 \mathrm{~g} \mathrm{~kg}^{-1}$ of dietary dry matter without negative effects to the leg tissue composition (\%) and physical parameters of confined sheep meat.
\end{abstract}

Key words: Agroindustrial waste. Meat color. Muscularity index.

\section{Resumo}

\begin{abstract}
Objetivou-se avaliar a composição tecidual da perna e os parâmetros físico-químicos de qualidade da carne de ovinos alimentados com níveis crescentes do subproduto do urucum (SU). Foram utilizados 32 animais machos, não castrados, sem padrão racial definido, casualizados em quatro tratamentos $\left(0,100,200\right.$ e $300 \mathrm{~g} \mathrm{~kg}^{-1}$ do subproduto do urucum na MS da dieta). Após 78 de confinamento, os animais foram abatidos e tiveram os componentes corporais registrados. O peso da perna reconstituída, peso total de músculos, peso do bíceps e peso do semitendinoso apresentaram comportamento linear negativo $(\mathrm{P}<0,05)$ com a inclusão do SU na dieta. Os parâmetros físico-químicos da carne (cor, força de cisalhamento, capacidade de retenção de água e perdas por cocção) não foram influenciados pela inclusão do SU na dieta. O subproduto do urucum pode ser incluído em até $300 \mathrm{~g} \mathrm{~kg}^{-1}$ da matéria seca da dieta sem efeitos negativos sobre a composição tecidual da perna (\%) e parâmetros físicos da carne de ovinos confinados.
\end{abstract}

Palavras-chave: Coloração da carne. Índice de musculosidade. Resíduo da agroindustrial.

Prof. Adjunto, Universidade Federal de Alagoas, UFAL, Arapiraca, AL, Brasil. E-mail: juniorzootec@yahoo.com.br

2 Profs. Titular, Universidade Federal Rural de Pernambuco, UFRPE, Recife, PE, Brasil. E-mail: ffrcarvalho@hotmail.com; m.ines@dcd.ufrpe.br

3 Profs. Associado, Universidade Federal do Rio Grande do Norte, UFRN, Natal, RN, Brasil. E-mail: stela_antas@yahoo.com.br; adrianohrangel@yahoo.com.br

4 Discente, Curso de Doutorado, Programa de Doutorado Integrado em Zootecnia, UFRPE, Recife, PE, Brasil. E-mail: jupaula. oliv@yahoo.com.br

* Author for correspondence 
Finishing lambs in confinement is not a usual practice among Brazilian sheep farmers, who traditionally adopt an extensive system of production. However, due to the good prospects for sheep meat marketing, it is necessary to intensify the finishing process of lambs in order to shorten the production cycle and to improve the quality of the carcass and the meat produced (SORIO et al., 2010).

In general, the variable costs associated with feeding animals in confinement represent the largest portion of the total operational cost of this system (BARROS et al., 2009). Due to climatic factors, the northeast region has no tradition in producing ingredients traditionally used in confined animal feed such as corn and soybeans, further exacerbating the cost of confinement practices in this region.

Alternatively, corn and soybeans can be substituted with coproducts from the agro-industry for feeding confined lambs. A coproduct that has aroused interest in Brazil results from the processing of a tropical shrub seed known as annatto (Bixa orellana L.) (RÊGO et al., 2010; VALÉRIO et al., 2015). This plant produces seeds rich in a dye-like carotenoid known as bixin; this carotenoid is mainly found in the layer of dust that covers the pericarp of the seed (FABRI; TERAMOTO, 2015). The food industry extracts the carotenoid and uses it as dye in more diverse products. The residue resulting from the extraction are seeds without this powder covering the pericarp, resulting in amounts of coproducts greater than $94 \%$ of the original product (BRITO et al., 2015). Considering that the annual production of annatto in Brazil exceeds 13 thousand tons, waste production of approximately 12 thousand tons can be inferred (BRAZ et al., 2007).

In a literature review, the chemical composition of the annatto coproduct (AC) showed average values of $870.0 \mathrm{~g} \mathrm{~kg}^{-1}$ dry matter (DM); $148.0 \mathrm{~g} \mathrm{~kg}^{-1}$ crude protein (CP); $22.0 \mathrm{~g} \mathrm{~kg}^{-1}$ ethereal extract (EE); $569.0 \mathrm{~g} \mathrm{~kg}^{-1}$ neutral detergent fiber (NDF); $301.0 \mathrm{~g}$ $\mathrm{kg}^{-1}$ acid detergent fiber (ADF); $23.4 \mathrm{~g} \mathrm{~kg}^{-1}$ lignin
(LIG); $206.0 \mathrm{~g} \mathrm{~kg}^{-1}$ non-fibrous carbohydrate (NFC). The estimate for the total digestible nutrient value (TDN) was $64.60 \%$ of the dry matter (PEREIRA et al., 2010).

Given the above, our objective was to evaluate the tissue composition of the leg and the physicalchemical parameters of sheep meat fed with increasing levels of annatto coproduct.

The experiment was carried in the municipality of Recife, state of Pernambuco in the following coordinates: $8^{\circ} 04^{\prime} 03$ ' $\mathrm{S}$ and $34^{\circ} 55^{\prime} 00^{\prime \prime} \mathrm{W}$, with an altitude of 4 meters. According to Koppen, the climate is classified as Ams', which is characterized as being hot and humid, with an average annual temperature of $25.2^{\circ} \mathrm{C}$.

Thirty-two uncastrated male sheep with no defined racial pattern were used, with a mean body weight of $23.17 \pm 1.45 \mathrm{~kg}$ and mean age of 8 months. The animals were distributed in a completely randomized design, totaling eight replications. The animals were treated for endoparasites and ectoparasites $\left(\right.$ Trimix $^{\circledR}$ ) and vaccinated against clostridiosis (Sintoxan ${ }^{\circledR}$ 9TH) at the beginning of the adaptation period. The experimental period lasted 78 days, with 20 days of adaptation and 58 days of data collection.

Throughout the experimental period, the animals remained in individual $1.0 \mathrm{~m}$ x $2.8 \mathrm{~m}$ stalls provided with feeder and drinking fountain, with water ad libitum. In this period, the food supply and leftovers as well as the animals were weighed to quantify food consumption and animal performance, respectively.

The treatments consisted of including four levels of annatto coproduct (AC) $(0,100,200$ and $300 \mathrm{~g}$ $\mathrm{kg}^{-1}$ ) to the dry matter diet (Table 1$)$. The control diet $\left(0 \mathrm{~g} \mathrm{~kg}^{-1}\right.$ of annatto coproduct) was formulated to meet requirements of male sheep weighing 25 $\mathrm{kg}$ for maintenance and gain of $200 \mathrm{~g}^{\text {day }}{ }^{-1}$ (NRC, 2007). The AC used in this study had the following composition: $858 \mathrm{~g} \mathrm{~kg} \mathrm{DM}$; $63.2 \mathrm{~g} \mathrm{~kg} \mathrm{MM;} 81.2 \mathrm{~g}$ $\mathrm{kg}$ EE; $145.5 \mathrm{~g} \mathrm{~kg} \mathrm{CP} ; 451.1 \mathrm{~g} \mathrm{~kg} \mathrm{NDF} ; 201.8 \mathrm{~g} \mathrm{~kg}$ ADF; $259.1 \mathrm{~g} \mathrm{~kg} \mathrm{NFC} \mathrm{and} 646.0 \mathrm{~g} \mathrm{~kg}$ TDN. 
Table 1. Proportion of ingredients and chemical composition (\% DM) of experimental diets.

\begin{tabular}{|c|c|c|c|c|}
\hline \multirow{2}{*}{ Ingredients } & \multicolumn{4}{|c|}{ Annatto coproduct levels $\left(\mathrm{g} \mathrm{kg}^{-1}\right)$} \\
\hline & 0 & 100 & 200 & 300 \\
\hline Tifton 85 , hay & 55 & 55 & 55 & 55 \\
\hline Corn, grain & 30 & 22.2 & 12.8 & 4.1 \\
\hline Soybean, meal & 13 & 10.8 & 10.2 & 8.9 \\
\hline Annatto, coproduct & 0 & 10 & 20 & 30 \\
\hline Urea & 1 & 1 & 1 & 1 \\
\hline Mineral salt & 1 & 1 & 1 & 1 \\
\hline \multirow[t]{2}{*}{ Total } & 100 & 100 & 100 & 100 \\
\hline & \multicolumn{4}{|c|}{ Chemical composition } \\
\hline $\mathrm{DM}^{1}$ & 878.5 & 876.5 & 874.7 & 872.8 \\
\hline $\mathrm{OM}^{2}$ & 943.7 & 940.0 & 935.3 & 931.5 \\
\hline $\mathrm{CP}^{2}$ & 154.0 & 151.2 & 154.6 & 155.3 \\
\hline $\mathrm{EE}^{2}$ & 44.5 & 43.7 & 41.5 & 39.9 \\
\hline $\mathrm{NDF}^{2}$ & 485.2 & 515.5 & 546.1 & 576.6 \\
\hline $\mathrm{ADF}^{2}$ & 249.9 & 266.0 & 282.0 & 298.1 \\
\hline $\mathrm{CHOT}^{2}$ & 745.3 & 745.2 & 739.3 & 736.4 \\
\hline $\mathrm{NFC}^{2}$ & 260.1 & 229.7 & 193.7 & 159.8 \\
\hline $\operatorname{ME}(\text { Mcal kg-1 })^{3}$ & 2.64 & 2.63 & 2.54 & 2.56 \\
\hline
\end{tabular}

After the confinement period, the animals were randomized in a slaughter order and fasted for 16 hours. The animals were weighed to obtain body weight at the time of slaughter, desensitized by cerebral concussion by non-penetrative percussion, suspended by the hind limbs using cords and bled by scission of the carotid arteries and jugular veins (BRASIL, 2000).

The bled, decapitated, skinned, eviscerated, amputated animal with kidneys and perirenal fat constituted the warm carcass. After obtaining hot carcass weights (HCW), the carcasses were taken to a cold chamber with an average temperature of $4^{\circ} \mathrm{C}$ where they remained for $24 \mathrm{~h}: 00 \mathrm{~min}$ suspended from hooks by the gastrocnemius muscle tendon. The left leg and the back of each animal were then vacuum packed in a high-density polyethylene bag 24h:00min post-mortem, identified and frozen in a freezer for further analysis.
Leg tissue composition was carried out through dissection according to the method described by Cezar and Sousa (2007). The five major muscles that surround the femur (Biceps femoris, Semimembranosus, Semitendinosus, Quadriceps femoris and Adductor) were removed and later weighed to calculate leg muscle index (LMI) according to the formula proposed by Purchas et al. (1991):

$$
\boldsymbol{L} \boldsymbol{M I}=\sqrt{ }(\boldsymbol{W} \mathbf{5} \boldsymbol{M} \div \boldsymbol{F} \boldsymbol{L})
$$

Where: W5M represents the weight of the five muscles $(\mathrm{g})$ and FL the length of the femur $(\mathrm{cm})$.

Cooking losses, shear strength and color were performed according to methodology described by Wheeler et al. (1993) adapted by Urbano et al. (2013). Water retention capacity (WRC\%) was determined according to the methodology proposed by Sierra (1973). 
Data were submitted to analysis of variance and regression. The models for regression were chosen based on the significance of the coefficients of determination and the biological behavior. $P$ values were significant at 0.05 probability for critical level of type I error. Statistical analyzes were performed using the Statistical and Genetic Analysis System (Sistema de Análises Estatísticas e Genéticas SAEG).

The inclusion of $\mathrm{AC}$ resulted in a negative linear effect $(\mathrm{P}<0.05)$ on leg weight $(\mathrm{g})$ and muscle weight (g) (Table 2). A reduction of 5.7 grams in the weight of the leg muscle was observed at each $1 \%$ inclusion of the coproduct. The negative linear effect on biceps weights $\left(\hat{\mathrm{Y}}=240.98-0.95 \mathrm{X} ; \mathrm{R}^{2}=0.96\right)$ and semitendinosus weight $(\hat{\mathrm{Y}}=98.63-0.45 \mathrm{X}$; $\left.\mathrm{R}^{2}=0.87\right) \quad(\mathrm{P}<0.05) \quad$ were probably responsible for the inclusion effect of $\mathrm{AC}$ on the absolute leg muscle mass weight. We can infer that the lower energy intake (Table 1) promoted by the by-product reduced muscle deposition in the leg of the sheep (ALMEIDA et al., 2009).

Table 2. Leg tissue composition of sheep fed with increasing levels of annatto coproduct.

\begin{tabular}{|c|c|c|c|c|c|c|c|c|}
\hline \multirow{2}{*}{ Variables } & \multicolumn{4}{|c|}{ Annatto coproduct levels $\left(\mathrm{g} \mathrm{kg}^{-1}\right)$} & \multirow{2}{*}{ Mean \pm SD } & \multicolumn{2}{|c|}{$\mathrm{P}$} & \multirow{2}{*}{$\mathrm{CV}(\%)$} \\
\hline & 0 & 100 & 200 & 300 & & $\mathrm{~L}$ & Q & \\
\hline Reconstituted leg (kg) & 2.53 & 2.48 & 2.46 & 2.32 & $2.45 \pm 0.21$ & $0.04^{1}$ & ns & 7.51 \\
\hline Muscle (kg) & 1.77 & 1.71 & 1.71 & 1.58 & $1.69 \pm 0.16$ & $0.01^{2}$ & ns & 8.14 \\
\hline Muscle (\%) & 70.07 & 69.32 & 69.24 & 68.41 & $69.26 \pm 2.22$ & ns & ns & 3.04 \\
\hline Bone (g) & 471.56 & 479.06 & 460.12 & 463.00 & $468.44 \pm 39.53$ & ns & ns & 8.90 \\
\hline Bone $(\%)$ & 18.73 & 19.42 & 18.73 & 20.05 & $19.23 \pm 1.75$ & ns & ns & 9.20 \\
\hline Fat $(\mathrm{g})$ & 178.50 & 180.56 & 204.50 & 159.69 & $180.81 \pm 57.01$ & ns & ns & 30.43 \\
\hline Fat $(\%)$ & 7.06 & 7.23 & 8.28 & 6.79 & $7.34 \pm 2.10$ & ns & ns & 28.47 \\
\hline Other tissues $(\mathrm{g})^{\mathrm{a}}$ & 104.69 & 104.44 & 94.12 & 110.62 & $102.72 \pm 33.11$ & ns & ns & 29.53 \\
\hline Other tissues (\%) & 4.13 & 4.03 & 3.74 & 4.74 & $4.16 \pm 1.17$ & ns & ns & 25.81 \\
\hline Muscle/bone ratio & 3.77 & 3.58 & 3.72 & 3.45 & $3.63 \pm 0.37$ & ns & ns & 10.29 \\
\hline Muscle/fat ratio & 10.51 & 10.02 & 8.90 & 11.17 & $10.15 \pm 2.73$ & ns & ns & 26.68 \\
\hline Leg muscle index & 0.38 & 0.37 & 0.37 & 0.36 & $0.37 \pm 0.02$ & ns & ns & 5.97 \\
\hline Lightness (L*) & 40.03 & 40.83 & 39.72 & 41.47 & $40.51 \pm 2.94$ & ns & ns & 7.64 \\
\hline Redness (a*) & 12.83 & 14.33 & 13.32 & 14.07 & $13.64 \pm 1.84$ & ns & ns & 13.22 \\
\hline Yellowness $\left(b^{*}\right)$ & 7.92 & 8.48 & 7.52 & 8.42 & $8.09 \pm 1.30$ & ns & ns & 16.83 \\
\hline $\mathrm{WRC}(\%)^{\mathrm{b}}$ & 27.74 & 30.28 & 27.84 & 27.26 & $28.28 \pm 0.83$ & ns & ns & 13.92 \\
\hline Cooking loss (\%) & 17.85 & 18.94 & 18.86 & 21.83 & $19.37 \pm 8.59$ & ns & ns & 40.20 \\
\hline Shear strength $\left(\mathrm{kg} \mathrm{cm}^{-2}\right)$ & 2.22 & 2.18 & 2.36 & 2.37 & $2.28 \pm 0.35$ & ns & ns & 16.05 \\
\hline
\end{tabular}

${ }^{\text {ns }}$ Non-significant; ${ }^{a}$ Lymph nodes, tendons, blood vessels, nerves etc.; ${ }^{\mathrm{b}}$ Water retention capacity. Equations: ${ }^{1} \hat{\mathrm{Y}}=2.54-$ $0.06 \mathrm{X}, \mathrm{R}^{2}=0.84 ;{ }^{2} \hat{\mathrm{Y}}=1.78-0.05 \mathrm{X}, \mathrm{R}^{2}=0.87$.

Despite the effect of $\mathrm{AC}$ on muscle weight (g), the tissue composition of the leg (\%) was not influenced by the inclusion of the coproduct, presenting an average of $69 \%$ of muscle, $19 \%$ of bone and $7 \%$ of fat.
On average, subcutaneous fat corresponded to $5.15 \%$ of the weight of the reconstituted leg, while the intramuscular fat corresponded to $1.83 \%$. This fat is late deposition and primarily provides subcutaneous protection against drip loss and 
darkening of muscle surfaces. Fat in the body of native sheep often has preferential deposition in the viscera and reduced deposition in the carcass (MIRKENA et al., 2010).

The ratio between mean subcutaneous fat/ intramuscular fat was 2.91, and it was not influenced $(\mathrm{P}>0.05)$ by the inclusion of annatto coproduct. Ratios between two and three are demanded by the refrigeration industry, mainly due to the reduction of drip losses.

No effects $(\mathrm{P}>0.05)$ of the inclusion of $\mathrm{AC}$ on the leg muscle index (LMI) were found, presenting a mean of 0.37 . The influence of $\mathrm{AC}$ on the weight of only two of the five muscles for obtaining this index can probably explain these results.

Color, cooking losses, water retention capacity and shear force physical-chemical parameters were not influenced $(\mathrm{P}>0.05)$ by the inclusion of $\mathrm{AC}$ in the diet (Table 2).

Lightness $\left(\mathrm{L}^{*}\right)$, redness intensity $\left(\mathrm{a}^{*}\right)$ and yellowness intensity $\left(b^{*}\right)$ were not influenced $(\mathrm{P}>0.05)$ by increasing levels of annatto coproduct. Lightness is influenced by water retention capacity, which was also not influenced $(\mathrm{P}>0.05)$ by the level of $\mathrm{AC}$ in the diet.

The coordinate redness intensity $\left(\mathrm{a}^{*}\right)$ is correlated with the amount of pigment in the meat and did not differ $(\mathrm{P}>0.05)$ between the treatments. The animals were slaughtered at a similar age and confined in similar sized bays, which probably contributed to the absence of a difference in myoglobin content in the muscle, and therefore in the coordinate $\mathrm{a}^{*}$.

Regarding the yellowness parameter (b*), an increase of this value was expected with the inclusion of annatto coproduct; however, this response was not verified $(\mathrm{P}>0.05)$. Annatto is rich in carotenoids that are deposited in the lipid fraction and therefore can modify meat coloration (DESCALZO; SANCHO, 2008; GARCIA et al., 2012). It is important to point out that the color measurements were made directly from slices of the Longissimus muscle, which presented poor or absent marbling and did not reflect the color of the deposited fat.

Water retention capacity (WRC) of the muscle was not influenced $(\mathrm{P}>0.05)$ by the increasing levels of $\mathrm{AC}$ and presented average values of $28.28 \%$. Water retention capacity observed in the present study was quite low (LAWRIE, 2005), and these values can be attributed to the type of freezing of the meat.

Shear force presented a mean of $2.28 \mathrm{~kg} \mathrm{~cm}^{-2}$ and was not influenced $(\mathrm{P}>0.05)$ by the addition of $\mathrm{AC}$ in the diet.

\section{Conclusion}

The inclusion of the annatto coproduct negatively influences leg muscle weight in confined sheep, but it has no effect on the physico-chemical characteristics of the meat.

\section{References}

ALMEIDA, T. R. V.; PÉREZ, J. R. O.; PAULA, O. J.; FRANÇA, P. M.; MACEDO JÚNIOR, G. L.; ASSIS, R. M. Efeito do nível de energia metabolizável na composição dos tecidos da carcaça de cordeiros da raça Santa Inês. Arquivo Brasileiro de Medicina Veterinária e Zootecnia, Belo Horizonte, v. 61, n. 1, p. 1364-1372, 2009.

BARROS, C. S.; MONTEIRO, A. L. G.; POLI, C. H. E. C.; DITTRICH, J. R.; CANZIANI, J. R. F.; FERNANDES, M. A. M. R. Rentabilidade da produção de ovinos de corte em pastagem e em confinamento. Revista Brasileira de Zootecnia, Viçosa, MG, v. 38, n. 11, p. 2270-2279, 2009.

BRASIL. Ministério da Agricultura. Instrução Normativa, $\mathrm{n}^{\circ} 3$, de 7 de janeiro de 2000. Regulamento técnico de métodos de insensibilização para o abate humanitário de animais de açougue. S.D.A./M.A.A. Diário Oficial [da] União, Brasília, 24 jan. 2000, Seção I. p. 14-16.

BRAZ, N. M.; FUENTES, M. F. F.; FREITAS, E. R.; SUCUPIRA, F. F.; MOREIRA, R. F.; LIMA, R. C. Semente residual do urucum na alimentação de poedeiras comerciais: desempenho e características dos ovos. Acta Scientiarum Animal Sciences, Maringá, v. 29, n. 2, p. 
129-133, 2007.

BRITO, J. G.; QUEIROZ, A. J. M.; FIGUEIRÊDO, R. M. F.; OLIVEIRA, A. S. Armazenamento de grãos residuais de urucum sob atmosfera controlada. Revista Brasileira de Engenharia Agrícola e Ambiental, Campina Grande, v. 19, n. 12, p. 1185-1191, 2015.

CEZAR, M. F.; SOUSA, W. H. Carcaças ovinas e caprinas: obtenção, avaliação e classificação. Uberaba: Editora Agropecuária Tropical, 2007. 232 p.

DESCALZO, A. M.; SANCHO, A. M. A review of natural antioxidants and their effects on oxidative status, odor and quality of fresh beef produced in Argentina. Meat Science, Illinois, v. 79, n. 3, p. 423-436, 2008.

FABRI, E. G.; TERAMOTO, J. R. S. Urucum: fonte de corantes naturais. Horticultura Brasileira, Vitória da Conquista, v. 33, n. 1, p. 140-140, 2015.

GARCIA, C. E. R.; BOLOGNESI, V. J.; DIAS, J. F. G.; MIGUEL, O. G.; COSTA, C. K. Carotenoides bixina e norbixina extraídos do urucum (Bixa orellana L.) como antioxidantes em produtos cárneos. Ciência Rural, Santa Maria, v. 42, n. 8, p. 1510-1517, 2012.

LAWRIE, R. A. Ciência da carne. 6. ed. São Paulo: Artimed Editora, 2005. 322 p.

MIRKENA, T.; DUGUMA, G.; HAILE, A.; TIBBO, M.; OKEYO, A. M.; WURZINGER, M.; SÖLKNER, J. Genetics of adaptation in domestic farm animals: a review. Livestock Science, Philadelphia, v. 132, n. 1, p. 1-12, 2010.

NATIONAL RESEARCH COUNCIL - NRC. Nutrient requirements of small ruminants: sheep, goats, cervids, and new world camelids. Washintgton: National Academyof Science, 2007. 347 p.

PEREIRA, E. S.; PIMENTEL, P. G.; DUARTE, L. S.; MIZUBUTI, I. Y.; ARAÚJO, G. G. L.; CARNEIRO, M. S. S.; REGADAS FILHO, J. G. L.; MAIA, I. S. G. Determinação das frações proteicas e de carboidratos e estimativa do valor energético de forrageiras e subprodutos da agroindústria produzidos no Nordeste
Brasileiro. Semina: Ciências Agrárias, Londrina, v. 31, n. 4, p. 1079-1094, 2010.

PURCHAS, R. W.; DAVIES, A. S.; ABDULlAH, A. Y. An objective measure of muscularity: changes with animal growth and differences between genetic lines of Southdown sheep. Meat Science, Illinois, v. 30, n. 1, p. 81-94, 1991.

RÊGO, A. C.; CÂNDIDO, M. J. D.; PEREIRA, E. S.; FEITOSA, J. V.; RÊGO, M. M. T. Degradação de silagens de capim-elefante contendo subproduto do urucum. Revista Ciência Agronômica, Fortaleza, v. 41, n. 3, p. 482-489, 2010.

SIERRA, I. Aportación al estudio del cruce Blanco belga $x$ Landrace: caracteres productivos, calidad de la canal y de la carne. Zaragoza: [s.n], 1973. 43 p. (IEPGE, n. 16).

SORIO, A.; CARFANTAN, J. Y.; MARQUES, W. A.; ARRUDA, D. O. Carne ovina: sistema internacional de comercialização. Passo Fundo: Méritos Editora, 2010. $142 \mathrm{p}$.

URBANO, S. A.; FERREIRA, M. A.; MACIEL, M. I. S.; DUTRA JÚNIOR, W. M.; ANDRADE, R. P. X.; SILVA, D. C. Tissue composition of the leg and meat quality of sheep fed castor bean hulls in replacement of tifton hay. Revista Brasileira de Zootecnia, Viçosa, MG, v. 42, n. 10, p. 759-765, 2013.

VALÉRIO, M. A.; RAMOS, M. I. L.; BRAGA NETO, J. A.; MACEDO, M. L. R. Annatto seed residue (Bixa orellana L.): nutritional quality. Food Science Technology, Campinas, v. 35, n. 2, p. 326-330, 2015.

WEISS, W. P. Energy prediction equations for ruminant feeds. In: CORNELL NUTRITION CONFERENCE FEED MANUFACTURES, 61., 1999, Ithaca. Proceedings... Ithaca: Cornell University, 1999. p. 176185.

WHEELER, T. T.; CUNDIFF, L. V.; KOCH, R. M. Effects of marbling degree on palatability and caloric content of beef. Beef Research Progress Report, Nebraska, v. 71, n. 4, p. 133-134, 1993. 